Waldemar K. Łuczaj

\title{
ON THE NEED OF REFORM OF TAX ENFORCEMENT SYSTEM IN POLAND
}

\section{Introduction}

One of the characteristic features of public finances is the fact that, unlike in case of private finances, the state has got coercive means to secure revenues (tax collection) while it is not subject to such coercion as far as expenditure is concerned (i.e. there are no coercive means against the state in this respect) ${ }^{1}$. The situation is reversed in the case of private persons - they have no coercive measures to secure their income whereas they can be forced to pay back their debts ${ }^{2}$.

The tax, as a public levy, is a charge characteristic of public finances. To secure a more or less regular budget income, the state supports a coercive apparatus ready to act in the case of refusal to pay this levy voluntarily - coercion is, in fact, inherent in tax systems. Therefore, to protect the state from the negative results of the indiscipline of taxpayers, tax authorities, acting in the capacity of public authority, are equipped with tax enforcement proceedings ${ }^{3}$. Due to numerous inconsistencies, casuistry, interpretation doubts, loopholes and inaccuracies of the regulations, these proceedings do not ensure effective tax enforcement. However, the problems with the application of the enforcement procedures are mostly due to the fact that the regulations, dating back to1966, are obsolete ${ }^{4}$.

Despite the fact that the Act on Enforcement Proceedings in Administration has been amended several dozen of times and uniform texts of the act have been issued

1 P.M. Gaudemet, J. Molinier, Finanse publiczne [Public Finances], Polskie Wydawnictwo Ekonomiczne, Warsaw 2000, p. 24.

2 lbid.

3 Currently in Polish Law, such proceedings are regulated by the Act of 17 June 1966 on Enforcement Proceedings in Administration (uniform text: Journal of Laws of 2005 No. 229, item 1594 with amds.) normalising the enforcement of pecuniary dues and non-pecuniary liabilities of public nature.

4 Z. Leoński, Administracyjne postępowanie egzekucyjne. Problemy węzłowe (Administrative Enforcement Proceedings. Key Issues), Wydawnictwo Wyższej Szkoły Bankowej w Poznaniu, Poznań 2003, p. 7. 
three times, its basic structure has remained unchanged. This is why the undertaken actions cannot be considered as a reform of tax enforcement system. The changes, introduced to the Act of 17 June 1966, were short-term and fragmentary, adapting the proceedings to new political, social and economic conditions. They were also connected with the necessity to adjust the provisions of the act to the EU regulations after Poland's accession to the European Union. A reform, on the other hand, involves long-term and comprehensive actions that will not be interrupted at the end of the term of the Parliament. Such actions are still to be undertaken by Polish legislators.

\section{Trends in legal regulations on tax enforcement at the turn of the $20^{\text {th }}$ and $21^{\text {st }}$ century in Poland}

The currently binding Act of 17 June 1966 on Enforcement Proceedings in Administration, regulating among other things tax enforcement, continuously required amendments predominantly due to political and socio-economic transformation. It was in 1990, however, when a political transformation in Poland began, that the introduction of wider changes became a must - up to this moment there had been only three amendments of little significance. After 1990 the amendments were so numerous (two amendments of 1990) that a uniform text of this act was issued in $1991^{5}$ and followed by new executive acts. Since then, the Act on Enforcement Proceedings in Administration has been amended several times. The most important amendments were introduced by the Act of 29 December 1998 on Amending Some Acts due to the Political Transformation of the State (Journal of Laws No. 162, item 1126), the Act of 8 December 2000 on amending the following acts: the Act on Enforcement Proceedings in Administration, the Local Taxes and Charges Act, the Act on State Subsidies to Interest on Some Kinds of Bank Loans, the Law on Public Trading in Securities, the Tax Ordinance Act, the Public Finances Act, the Corporate Income Tax Act, the Act on the Commercialisation and Privatisation of State Enterprises - related to adjusting Polish law to EU regulations (Journal of laws of 2001 No.122, item 1315) and the Act of 6 September 2001 on amending the Act on Enforcement Proceedings in Administration and some other acts (Journal of Laws No. 125, item 1368).

The most extensive and significant amendment in recent years was beyond doubt the Act of 6 September 2001 on amending the Act on Enforcement Proceedings in Administration and some other acts (Journal of Laws No. 125, item 1368). It aimed to adapt the above mentioned act to current social and economic reality, particularly in terms of enforcement of pecuniary dues, as well as to make certain regulations more precise. 
Due to the currently binding Constitution, it was also essential to incorporate into the very act a number of regulations on executive bodies, fees and expenses, which up to then had been included in executive regulations only. Furthermore, it was necessary to contain within the Constitution regulations related to the appointment of tax chamber-registered property appraisals and tender procedures for the sale of movables.

These changes were primarily meant to improve the efficiency of tax enforcement system, which would consequently lead to the improvement of the condition of public finances sector, and finally cause the acceleration of economic growth. As a result, the regulation became an element of the middle-term financial strategy prepared by the Ministry of Finance. ${ }^{6}$

In order to implement these principles, the range of enforcement measures applied in enforcement proceedings related to pecuniary dues was extended, i.e. within the framework of the provisions specifying the enforcement of pecuniary dues from other pecuniary liabilities and property rights, new regulations were introduced to cover the amounts due from:

- rights stemming from securities registered in securities accounts,

- securities not registered in securities accounts,

- bills of exchange,

- copyright and related rights, as well as industrial property rights,

- shares in commercial companies and partnerships.

Moreover, a new enforcement measure, enabling to cover the amounts due from real estate, which was up to then reserved for court enforcement proceedings, was introduced. The underlying reasons for this step were both economic and organisational.

In addition to the changes listed here, the Act of 6 September 2001 on amending the Act on Enforcement Proceedings in Administration and some other acts introduced a series of other changes meant to make the enforcement of pecuniary dues more efficient. These changes were slightly less significant though. 


\section{Contemporary problems of tax enforcement in Poland}

Frequent amendments to the Act on Enforcement Proceedings in Administration so far have not resulted in the expected increase of the efficiency of administrative enforcement of pecuniary means. On the contrary, in recent years we witness deterioration in the coercive enforcement of all pecuniary dues performed by the Heads of Tax Offices, which is explicitly shown in table $1^{7}$ :

\section{Table 1}

\begin{tabular}{||c|c|c|c|c|c|c||}
\hline \begin{tabular}{c}
\hline \\
Year
\end{tabular} $\begin{array}{c}\text { Number of writs } \\
\text { of execution to } \\
\text { be settled in the } \\
\text { reporting period } \\
\text { (along with the initial } \\
\text { balance) }\end{array}$ & $\begin{array}{c}\text { Number of writs } \\
\text { of execution } \\
\text { settled in the } \\
\text { reporting period }\end{array}$ & $\begin{array}{c}\text { Ratio of } \\
\text { settled writs of } \\
\text { execution in \% } \\
(4: 3)\end{array}$ & $\begin{array}{c}\text { Amount of arrears } \\
\text { covered by writs } \\
\text { of execution to be } \\
\text { settled (in thousand } \\
\text { PLN) }\end{array}$ & $\begin{array}{c}\text { Amount of } \\
\text { tax arrears } \\
\text { enforced (in } \\
\text { thousand PLN) }\end{array}$ & $\begin{array}{c}\text { Enforcement } \\
\text { ratio in \% }\end{array}$ \\
\cline { 2 - 7 } 2004 \\
\cline { 2 - 7 } 2005 & 15747569 & 5903114 & $37,49 \%$ & 11832215 & 2541508 & $21,48 \%$ \\
\hline 11797665 & 6396698 & $35,94 \%$ & 13264040 & 2631268 & $19,84 \%$ \\
\hline
\end{tabular}

According to the Ministry of Finance, this poor performance is the result of the level of employment which is too low in comparison to the systematically growing number of writs of execution to be settled ${ }^{8}$. Table 2 depicts how the level of workload of tax enforcement services in tax offices changed in 2003-2006 :

\section{Table 2}

\begin{tabular}{|c|c|c|c|c|c|c||}
\hline Period & $\begin{array}{c}\text { Number of writs } \\
\text { of execution to } \\
\text { be settled }\end{array}$ & $\begin{array}{c}\text { Dynamics (the } \\
\text { previous period } \\
=100)\end{array}$ & $\begin{array}{c}\text { Number of } \\
\text { employees }\end{array}$ & $\begin{array}{c}\text { Dynamics (the } \\
\text { previous period } \\
\text { = 100) }\end{array}$ & $\begin{array}{c}\text { Average number of } \\
\text { writs of execution } \\
\text { to be settled by one } \\
\text { employee }\end{array}$ & $\begin{array}{c}\text { Dynamics (the } \\
\text { previous period } \\
=100)\end{array}$ \\
\hline 1 & 2 & 3 & 4 & 5 & 6 & 7 \\
\hline 2003 & 12800247 & $X$ & 4018 & $X$ & 3186 & $X$ \\
\hline 2004 & 15747569 & $123,03 \%$ & 4090 & $101,79 \%$ & 3850 & $120,86 \%$ \\
\hline 2005 & 17797665 & $113,02 \%$ & 4090 & $100,00 \%$ & 4352 & $113,02 \%$ \\
\hline 2006 & 19333369 & $108,63 \%$ & 4154 & $101,56 \%$ & 4654 & $106,96 \%$ \\
\hline
\end{tabular}

\footnotetext{
$7 \quad$ The answer of the undersecretary of the state in the Ministry of Finance, acting on behalf of the Minister, to the parliamentary question No. 7202 about raising the revenues from the collection of goods and services tax by tax offices. See the website of the Sejm: http://www.sejm.gov.pl.

8 Ibid.

9 Ibid.
} 
A low increase in employment combined with a high rise in the number of writs of execution to be settled leads to a continuously growing workload in tax enforcement units of tax offices. For instance, the number of execution writs to be settled by one employee in 2006 increased by 46,08\% compared with 2003 . Consequently, although in consecutive years the enforcement services managed to settle more and more writs of execution, hence collecting more and more amounts due, the efficiency of tax enforcement has not improved ${ }^{10}$.

Both representatives of doctrine and practitioners point to other factors that have impact on the deteriorating efficiency of enforcement of pecuniary dues ${ }^{11}$, in particular such as:

- imputation of considerable tax arrears based on post-audit decision as a result of proving fictional transactions which cannot be subject to efficient enforcement proceedings (e.g. due to the failure of fiscal inspection authorities to submit applications for securing the satisfaction of tax liabilities prior to determining such liabilities),

- impossibility to collect tax arrears from debtor's assets that are subject to enforcement proceedings, e.g. lack of funds in the debtor's bank account, salaries received by a debtor lower than the amounts subject to enforcement, etc.,

- lack of assets that could be subject to enforcement proceedings,

- debtor's assets encumbered with a registered pledge to the benefit of banks resulting from bank loans taken out by a debtor,

- difficult to enforce tax arrears from previous reporting periods that were subject to enforcement proceedings that proved to be ineffective or that resulted in collecting only a very insignificant sum,

- rise in uncollectible arrears owed by business entities as well as by natural persons who no longer run privately-owned businesses,

- rise in the number of debtors whose assets are more difficult to determine, which in consequence significantly extends the length of proceedings,

- problems with establishing debtor's place of residence, the fact that debtors are abroad, both of which make the assessment of their assets impossible, 
- lengthy judicial proceedings to disclose debtor's assets and compulsory mortgages, as well as lengthy penal proceedings against the debtors who evade paying their tax obligations,

- low efficiency of judicial proceedings to disclose debtor's assets,

- division of marital property,

- growing number of enforcement proceedings conducted simultaneously by both courts and administration units, which considerably extends the length of proceedings,

- problems with covering tax obligations from property rights, in particular from shares and copyright, due to insufficient information on holding such rights by debtors;

- low efficiency of enforcement proceedings taken or reopened to collect tax arrears that due to the taxpayer's failure to meet the statutory requirements have not been cancelled in the course of previous restructuring proceedings,

- low efficiency of covering tax obligations from movables,

- unsatisfactory efficiency of covering tax liabilities from real estate,

- but also:

- problems with the application of the binding law by the employees of tax enforcement units of tax offices due to the inadequacy to reality, instability, and ambiguity of the regulations, as well as changing interpretations of the said regulations by the Ministry of Finance, tax chambers, and courts,

- insufficient level of knowledge and competence of enforcement employees resulting from no opportunities for their professional development, i.e. especially higher and post-diploma study programmes, apart from few opportunities of internal and departmental training courses,

- lack of adequate inspection over tax enforcement services, in particular lack of internal audit.

\section{Conclusions}

Our discussion proves that short-term and fragmentary solutions introduced to the regulations on tax enforcement system in Poland are definitely not enough to reform this system. To achieve the results that live up to our expectations, the changes must be comprehensive and concern not only legal regulations but also organisational issues. Therefore, according to the author of the present paper, we 
should support the recommendations on the most important aspects of the reform of tax enforcement system, raised by some representative of the doctrine. These assumptions include ${ }^{12}$ :

1. Organisation of regulations. With the above in mind, it is legitimate to call for a new act on enforcement proceedings in administration dealing exclusively with the enforcement proceedings of pecuniary dues, thus resulting in the separation of enforcement of pecuniary dues and non-pecuniary obligations. Such a solution seems to be well-grounded due to fundamental differences inherent to these two proceedings, e.g. different nomenclature, application of dissimilar means of execution, etc. Furthermore, we should insist that relevant regulations of the Tax Ordinance Act of 29 August 1997 (uniform text: Journal of Laws of 2005 No. 8, item 60, with amds.) be used in enforcement proceeding of pecuniary dues instead of the regulations contained in the Administrative Procedure Code of 14 June 1960 (uniform text: Journal of Laws of 2005 No. 98, item 1071 with amds) that have been applied so far, as the former would be more relevant to the nature of enforced dues. Still, these regulations should be adapted to the present socio-economic and political situation and aimed at simplifying the procedures.

2. Reorganisation of administrative enforcement services. The reorganisation should aim to establish executive bodies at the provincial level. Locating such authorities in the capitals of the provinces would facilitate concentrating in such cities, qualified and competent staff that would manage to deal with more difficult enforcement proceeding, including the collection of dues from real estate. Following the pattern of Polish regulations dating back to the early thirties of the previous century, we should also consider appointing two separate executive bodies for the tax enforcement and for the enforcement of other pecuniary dues respectively.

3. Establishing a departmental system of education for fiscal staff, taking into account the needs of enforcement services. The best instrument of the policy of educating fiscal employees would be establishing a specialised higher education institution in imitation of the solution adopted in Germany for instance. Currently, departmental institutions responsible for training courses fail to fulfil this function. At present, the requirements faced by the employees dealing with enforcement proceedings are by no means excessive. It is sufficient that the tax enforcement officer, also the head of the enforcement unit in a tax office, dealing with tax enforcement inter alia holds a higher education qualification whereas for other employees of the unit it is enough to have secondary education. Such requirements are incomparable with those 
faced by court bailiffs, who need to hold a higher education qualification in law, serve a two-year pupilage, pass an examination for a bailiff, and, on top of these, work for at least two years as an assistant bailiff.

4. Making the institution of internal audit more widespread and operating better. The internal audit should be specialised in enforcement related issues and prepared to improve the performance of enforcement services by carrying out complex analyses of influential factors on and impediments to the functioning of enforcement apparatus, which would facilitate ex ante sanative actions.

To sum up, a real reform of tax enforcement system in Poland requires not only a new act regulating the administrative enforcement proceedings of pecuniary dues but also the one on the administrative system of enforcement authorities. Implementing the above mentioned recommendations, these acts should also introduce legal instruments to ensure fast, efficient and effective performance of administrative enforcement apparatus in current socio-political and socio-economic situation, at the same time complying with all standards necessary for the validity of legal system and ensuring the rights of its participants. Free of excessive formalisation, these regulations should introduce lucid principles governing the actions of enforcement authorities, creditors, debtors and other persons involved in the administrative enforcement proceedings as well as transparent rules determining the responsibility for taking action or failing to act.

The reform of tax enforcement system in Poland is of the outmost urgency as the efficiency of enforcing this public levy is one of the key factors influencing the financial condition of the state. Similarly, it plays a crucial role in the efficiency of state's public authority to exert influence both in cases when the debtors evade satisfying their obligations and on the extent in which individuals and legal persons voluntarily fulfil their obligations. 


\section{Streszczenie}

Obecnie obowiązująca ustawa z dnia 17 czerwca 1966 r. o postępowaniu egzekucyjnym w administracji, regulując także egzekucję podatków, ciagle wymaga nowelizacji wynikających z politycznej i społeczno-ekonomicznej transformacji. Pomimo podejmowanych czynności nowelizacyjnych, nie mogą być one rozważane jako reforma systemu egzekucji zobowiązań podatkowych. Zapronowane zmiany okazały się krótkotrwałe i fragmentaryczne. Co więcej, nie przyniosły poprawy w zakresie wzrostu skuteczności podejmowanych egzekucji.

Artykuł ten dowodzi, że prawdziwa reforma systemu egzekucji podatków w Polsce wymaga nie tylko nowej ustawy regulującej samą procedurę, ale także nowych przepisów dotyczących całego systemu egzekucji administracyjnej. 